\title{
Highly active supported palladium catalyst for the regioselective synthesis of 2-arylpropionic acids by carbonylation
}

\author{
S. Jayasree, A. Seayad and R. V. Chaudhari* \\ Homogeneous Catalysis Division, National Chemical Laboratory, Pune- 411 008, India. E-mail: rvc@ems.ncl.res.in
}

Received (in Cambridge, UK) 30th March 1999, Accepted 5th May 1999

\begin{abstract}
A catalyst system consisting of supported palladium in the presence of phosphine ligands, TsOH and $\mathrm{LiCl}$ catalyses the carbonylation of 1-arylethanols to 2-arylpropionic acids with significantly improved activity and regioselectivity; the catalyst can be recycled with no loss in activity and selecivity.
\end{abstract}

Carbonylation of 1-arylethanols is of great interest since it provides an environmentally benign route ${ }^{1}$ for the synthesis of anti-inflammatory drugs such as Ibuprofen, Naproxen etc. The importance of this route can be clearly demonstrated from the commercialisation of an Ibuprofen process at Texas in 1992 by Hoechst Celanese Corporation based on the carbonylation of 1-(4-isobutylphenyl)ethanol using a palladium complex catalyst. ${ }^{2}$ The desired high selectivity (>98\%) for Ibuprofen was achieved only at very high pressures $^{3}(16-34 \mathrm{MPa})$. This homogeneous palladium catalyst system gave lower $\mathrm{TOF} \dagger$ $\left(50-100 \mathrm{~h}^{-1}\right)$ and selectivity $(<68 \%)$ at lower pressures $(\sim 6.8$ MPa). ${ }^{4}$ Additives such as $\mathrm{CuCl}_{2}$ were reported to improve the selectivity under similar conditions. ${ }^{5}$ In another study, a biphasic catalyst with a water soluble palladium complex ${ }^{6}$ has been reported but in this case also, very low reaction rates (TOF $=2.3 \mathrm{~h}^{-1}$ ) and lower Ibuprofen selectivity (70\%) were observed.

Here we report, for the first time, highly active and selective supported palladium and platinum catalyst systems for the synthesis of 2-arylpropionic acids from the corresponding 1-arylethanols. Supported palladium combined with $\mathrm{PPh}_{3}, \mathrm{LiCl}$ and $\mathrm{TsOH}$ provides very high TOF $\left(3375 \mathrm{~h}^{-1}\right)$ and more importantly high selectivity $(99.5 \%)$ for 2-arylpropionic acids at lower pressures (5.4 MPa). The activity as well as the selectivity was substantially higher compared to previous reports under identical conditions. The catalyst was recycled four times with no loss in activity and selectivity, attaining a total TON of 55,000 . These results indicate that this new catalyst system $\left(\mathrm{Pd}-\mathrm{C} / \mathrm{PPh}_{3} / \mathrm{TsOH} / \mathrm{LiCl}\right)$ is highly efficient and provides significant improvement over the current state of the art for the synthesis of 2-arylpropionic acids.

In a typical experiment, the supported catalyst, $\ddagger$ the substrate, the phosphine ligand, $\mathrm{LiCl}, \mathrm{TsOH}, \mathrm{H}_{2} \mathrm{O}$ and the solvent (methyl ethyl ketone) were charged into a stirred pressure reactor and the reaction was carried out at $5.4 \mathrm{MPa}$ of $\mathrm{CO}$ partial pressure at $115^{\circ} \mathrm{C}$ under $1100 \mathrm{rpm}$ for a specified time. The reaction mixture was analysed by gas chromatography $\S$ and the products were further characterized by GC-MS and NMR.

Typical results for the carbonylation of 1-(4-isobutylphenyl)ethanol ( $p$-IBPE) using different catalysts, supports, promoters and ligands are presented in Table $1 . \mathrm{Pt} / \mathrm{C}$ provided comparatively lower activity than $\mathrm{Pd} / \mathrm{C}$. Other supports such as $\gamma$ alumina and H-ZSM-5 were also useful. Different acid and halide sources were checked and were found to not significantly effect the catalytic activity. The nature of the phosphine ligand has a strong influence on the catalytic activity, as evidenced from Table 1. No reaction was observed with diphos ligands such as dppb, unlike the catalyst system reported by Ali et al. for the carbonylation of olefins. ${ }^{7}$

It was important to understand whether the reaction occurs heterogeneously or homogeneously (by soluble complexes of $\mathrm{Pd}$ formed in situ). For this purpose, liquid phase reaction
Table 1 Carbonylation of 1-(4-isobutylphenyl)ethanol ( $p$-IBPE) to give Ibuprofen using supported palladium and platinum catalysts ${ }^{a}$

\begin{tabular}{llcllr}
\hline Catalyst & Ligand & $t / \mathrm{h}$ & $\begin{array}{l}\text { Conver- } \\
\text { sion }(\%)\end{array}$ & $\begin{array}{l}\text { Selec- } \\
\text { tivity }(\%)\end{array}$ & $\mathrm{TOF} / \mathrm{h}^{-1}$ \\
\hline $1 \% \mathrm{Pd} / \mathrm{C}$ & $\mathrm{PPh}_{3}$ & 4.2 & 96 & 99.2 & 3375 \\
$1 \% \mathrm{Pd} / \gamma$-alumina & $\mathrm{PPh}_{3}$ & 5.5 & 92 & 99.5 & 2475 \\
$1 \% \mathrm{Pd} / \mathrm{H}-\mathrm{ZSM}-5$ & $\mathrm{PPh}_{3}$ & 5.8 & 90 & 99.0 & 2285 \\
$1 \% \mathrm{Pt} / \mathrm{C}$ & $\mathrm{PPh}_{3}$ & 24 & 90 & 99.2 & 550 \\
$\mathrm{Pd} \mathrm{metal}{ }^{b}$ & $\mathrm{PPh}_{3}$ & 8 & 97 & 99.3 & 90 \\
$1 \% \mathrm{Pd} / \mathrm{C}$ & $\mathrm{P}(p-\mathrm{Tol})_{3}$ & 4.5 & 94 & 98.5 & 3062 \\
$1 \% \mathrm{Pd} / \mathrm{C}$ & $\mathrm{P}(p-\mathrm{FPh})_{3}$ & 5.9 & 95 & 99.5 & 2384 \\
$1 \% \mathrm{Pd} / \mathrm{C}$ & $\mathrm{P}(\mathrm{Cy})_{3}$ & 24 & 50 & 99.5 & 308 \\
$1 \% \mathrm{Pd} / \mathrm{C}^{c}$ & $\mathrm{PPh}_{3}$ & 8 & 91 & 99.0 & 1676 \\
$1 \% \mathrm{Pd} / \mathrm{C}^{d}$ & $\mathrm{PPh}_{3}$ & 6 & 93 & 98.5 & 2272
\end{tabular}

a Conditions: $p$-IBPE (14.04 mmol), catalyst $(10 \mathrm{mg})$, phosphine $(0.1908$ $\mathrm{mmol}), \mathrm{TsOH}(5.6052 \mathrm{mmol}), \mathrm{LiCl}(5.6052 \mathrm{mmol}), \mathrm{H}_{2} \mathrm{O}(67 \mathrm{mmol})$, methyl ethyl ketone $(21 \mathrm{ml}), P_{\mathrm{CO}}=5.4 \mathrm{MPa}, T=115^{\circ} \mathrm{C} .{ }^{b} \mathrm{Pd}$ metal $(2 \mathrm{mg}){ }^{c} \mathrm{HCl}$ (5.6052 mmol) instead of $\mathrm{TsOH}$ and $\mathrm{LiCl} .{ }^{d} \mathrm{Bu}_{4} \mathrm{NCl}$ instead of $\mathrm{LiCl}$.

samples were withdrawn during reaction and also after the end of the reaction (on cooling of the contents). The analysis of the liquid phase, after the reaction, for $\mathrm{Pd}$ content by atomic absorption spectroscopy showed $<0.1 \mathrm{ppm}$ of $\mathrm{Pd}$ in solution, but the sample withdrawn under the reaction conditions showed significant leaching of $\mathrm{Pd}(1.5 \mathrm{ppm} \mathrm{Pd})$. This indicates that the reaction is more likely to be homogeneously catalysed and the enhanced activity and selectivity is due to the combination of $\mathrm{Pd}$ with $\mathrm{PPh}_{3}$ and promoters like TsOH, and $\mathrm{LiCl}$. At the same time, readsorption of $\mathrm{Pd}$ onto the support after the reaction facilitates repeated recycling. Thus, the proposed catalyst system offers significant advantages, not only with respect to activity and selectivity, but also to catalyst recycling.

Intermediate sampling for the carbonylation of $p$-IBPE showed that the reaction proceeds through the formation of 4-isobutylstyrene and 1-(4-isobutylphenyl)ethyl chloride as the intermediates. Here the question was, which intermediate is undergoing carbonylation? To make this point clear, the carbonylation of 4-isobutylstyrene was performed in the absence of $\mathrm{LiCl}$. The reaction was found to be very slow (TOF $=300 \mathrm{~h}^{-1}$ ) with very poor Ibuprofen selectivity $(65 \%)$. But in

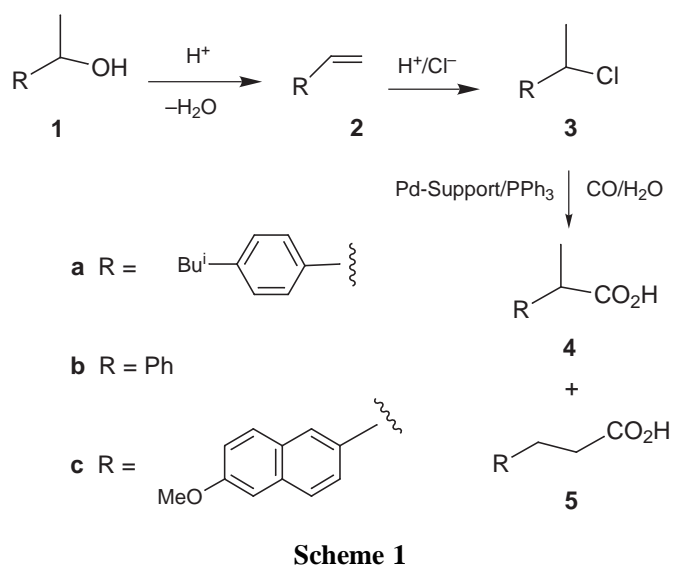

Chem. Commun., 1999, 1067-1068 
Table 2 Synthesis of 2-arylpropionic acids by carbonylation ${ }^{a}$

\begin{tabular}{lclll}
\hline Substrate & \multirow{2}{*}{ h } & Conversion $(\%)$ & Selectivity $(\%)$ & $\mathrm{TOF} / \mathrm{h}^{-1}$ \\
\hline $\mathbf{1 a}$ & 4.2 & 96 & 99.2 & 3375 \\
$\mathbf{2 a}$ & 4 & 92 & 99.1 & 3400 \\
$\mathbf{3 a}$ & 4 & 90 & 99.3 & 3300 \\
$\mathbf{1 b}$ & 13 & 90 & 98 & 1010 \\
$\mathbf{2 b}$ & 4.6 & 92 & 98 & 2900 \\
1c & 24 & 90 & 99 & 552
\end{tabular}

a Conditions: Substrate $(14.04 \mathrm{mmol})$, catalyst $(10 \mathrm{mg})$, phosphine $(0.1908$ $\mathrm{mmol}), \mathrm{TsOH}(5.6052 \mathrm{mmol}), \mathrm{LiCl}(5.6052 \mathrm{mmol}), \mathrm{H}_{2} \mathrm{O}(67 \mathrm{mmol})$, methyl ethyl ketone $(21 \mathrm{ml}), P_{\mathrm{CO}}=5.4 \mathrm{MPa}, T=115^{\circ} \mathrm{C}$.

the presence of $\mathrm{LiCl}$ the catalytic activity and Ibuprofen selectivity were the same as that of $p$-IBPE carbonylation. Under similar conditions, 1-(4-isobutylphenyl)ethyl chloride also showed the same catalytic activity and selectivity behaviour. This indicates that in the presence of $\mathrm{LiCl}$, the major reaction pathway is the carbonylation of the chloro derivative, as shown in Scheme 1.

The catalyst system was also applicable for the carbonylation of various 1-arylethanols and their corresponding olefin and chloro analogues, as demonstrated in Table 2 . In all cases, high TOF and 2-arylpropionic acid selectivity were achieved.

In summary, in the presence of phosphines, $\mathrm{TsOH}$ and $\mathrm{LiCl}$, with supported palladium and platinum as the catalyst systems, the carbonylation of 1-arylethanols to 2-arylpropionic acids occurs with high activity and regioselectivity with efficient recycling of the catalyst.

S. J. and A. S. thank the Council of Scientific and Industrial Research, India, for a research fellowship.

\section{Notes and references}

$\dagger$ TOF $=$ Turn over frequency $=$ number of moles of Ibuprofen produced per mole of metal per hour.

$\$$ The catalysts were prepared by wet impregnation of the chloride salts of the metals followed by reduction using formaldehyde (for carbon) or sodium formate (for alumina and H-ZSM-5).

$\S$ Analysis of the components was by GC (FFAP capillary column $25 \mathrm{~m} \times$ $0.2 \mathrm{~mm}$, FID)

1 R. A. Sheldon, Chem. Ind., 1992, 903; C. B. Dartt and M. E. Davis, Ind. Eng. Chem. Res., 1994, 33, 2887.

2 J. N. Armor, Appl. Catal., 1991, 78,141

3 V. Elango, D. G. Kenneth, M. M. Alan, M. N. Graham, Z. G. Edward and S. B. Lee, EP 400 892, 1990.

4 A. Seayad, A. A. Kelkar and R. V. Chaudhari, Stud. Surf. Sci. Catal., 1998, 113, 883.

5 E. J. Jang, K. H. Lee, J. S. Lee and Y. G. Kim, J. Mol. Catal. A: Chem., 1999, 138, 25.

6 G. Papadogianakis, L. Maat and R. A. Sheldon, J. Chem. Technol. Biotechnol., 1997, 70, 83; G. Papadogianakis, G. Verspui, L. Maat and R. A. Sheldon, Catal. Lett., 1997, 47, 43.

7 B. E. Ali, G. Vasapollo and H. Alper, J. Org. Chem., 1993, 58, 4739.

Communication 9/02541C 